Measuring Consumers' Intention to Use Aggregator Food Ordering ...

Dr/ Sally Raouf Ragheb Garas

\title{
Measuring Consumers' Intention to Use Aggregator Food Ordering and Delivery Mobile Apps: a post COVID19 examination
}

\author{
Dr/ Sally Raouf Ragheb Garas \\ LECTURER OF MARKETING \\ Pharos University in Alexandria (PUA)
}

\section{Abstract}

The purpose of the study is to examine the impact of perceived ease of use, perceived usefulness and technology involvement on intention to use aggregator food ordering and delivery mobile apps. A single cross sectional descriptive research was conducted. questionnaires were gathered from 257 aggregator food ordering and delivery mobile app users. Regression was used to test the hypotheses. Results indicate that perceived usefulness, followed by technology involvement then perceived ease of use have significant positive impacts on intention to use aggregator food ordering m-apps

\section{Introduction}

Because of COVID19 pandemic and during the lockdown period in 2020, many consumers worldwide shifted their shopping behavior from physical store visits to virtual shopping; ordering and paying online or ordering and paying on delivery. This behavioral trend continued after lockdown period as consistent with the social distancing requirement. Indeed, digital marketing 
Measuring Consumers' Intention to Use Aggregator Food Ordering ...

Dr/ Sally Raouf Ragheb Garas

channels, including mobile marketing, were regarded as facilitating tools for social distancing, as they enable consumers to obtain services without visiting physical stores (Leon, 2018). Consequently, many companies realized that digital marketing is no longer a choice but a vital marketing communications channel to survive in the current era.

Mobile marketing is one of the traditional direct marketing channels which has long been used by firms to get closer to their target markets. Since the introduction of smartphones, and the extensive daily use of it by most adults, mobile marketing has both undergone major developments and gained much importance as a marketing communication tool, one of which is the development and use of mobile applications or mobile apps (m-apps) hereafter (Soomro, et al., 2019). Especially that, from a business perspective, smartphones are regarded as useful tools for behavioral targeting enabling marketers to provide personalization, mobility and interactivity.

The current study aims to examine the impact of perceived ease of use, perceived usefulness of aggregator food delivery m-apps as well as the impact of technology involvement on consumers' intention to use aggregator food-delivery mobile apps (m-apps), which are digital platforms for many food service providers, especially after COVOD19 pandemic and the need for social distancing. There is a need to study the impact of these factors since food delivery apps were among the top m-apps downloaded 
Measuring Consumers' Intention to Use Aggregator Food Ordering ...

Dr/ Sally Raouf Ragheb Garas

in 2020 (Code 95 Egyptian Web Technology, 2020) and are among the most developed m-apps (Patsiotis et al., 2020). Given that technology involvement is a recently studied concept in the context of mobile marketing and Technology Acceptance Model (TAM) (Calvo-Porral and Nieto-Mengotti, 2019). The study is expected to have implications on aggregator food delivery mapps providers, developers and eventually end-users.

The remaining of the research consists of the literature review, the research hypotheses, the proposed model, research methodology, data analysis and findings, and finally the implications, recommendations and limitations.

\section{Literature Review}

\subsection{Mobile Marketing and M-apps: An Overview}

According to the Mobile Marketing Association (2009), mobile marketing "is a set of practices that enable organizations to communicate and engage with their audience in an interactive and relevant manner through any mobile device or network."

Mobile marketing for a long time has utilized push promotional strategies, that is sending content to the mobile user at a time other than what the user requests. Push mobile marketing includes mobile telemarketing, Short Message Services (SMS) and Mobile Display Advertising (MDA) (Leppaniemi and Karjaluoto, 2008). Lately, due the developments in Information and Communications Technology (ICT), the adoption of smartphones by most consumers and the negative attitude which 
Measuring Consumers' Intention to Use Aggregator Food Ordering ...

Dr/ Sally Raouf Ragheb Garas

many consumers hold regarding push mobile marketing, have increasingly motivated marketers to use pull mobile marketing, especially m-apps, to encourage consumers to seek their products (Patsiotis et al., 2020; Kushwaha and Agrawal, 2016).

M-apps are software designed to perform certain tasks on personal mobile devices such as smartphones and tablets (Tang, 2019). They are considered as a retailers' virtual store providing advantages as security features, less clutter, more interactivity and personalized features (Nair and Bhattacharyya, 2019). Previous literature provides a number of classifications for $\mathrm{m}$ apps, namely five main classifications, which are category mapps, branded versus aggregator m-apps, revenue-generating versus branded m-apps, paid versus free m-apps and finally, information seeking versus information sharing apps. The following is an illustration of these main classifications (Hew, et al., 2015; Tsalgatidou and Pitoura, 2001; Stocchi et al., 2019; Nair and Bhattacharyya, 2019; Tang, 2019; Son, 2017).

Firstly, category m-apps are based on the function they perform, such as productivity and tools, entertainment and music, shopping, fitness, games, healthcare...etc.

Secondly, branded versus aggregator m-apps. Branded m-apps are attributed to the product's source/provider and display the brand identity. Aggregator (third-party) m-apps are apps used by the provider to outsource the marketing activities, where the app displays the provider's products and supports ordering, logistics 
Measuring Consumers' Intention to Use Aggregator Food Ordering ...

Dr/ Sally Raouf Ragheb Garas

and payments systems through secured transactions. Hence, aggregator m-app is a platform for many product providers.

Thirdly, revenue-generating versus branded m-apps. Branded mapps support the main brand, while revenue-generating apps represent a business by themselves.

Fourthly, paid versus free apps. Paid m-apps entail the user to pay a price before downloading, while fee apps are downloaded for free, providing users with either limited features and allowing in-app purchases to permit them to use additional features or provide them with full features but include in-app advertising.

Fifthly, information-seeking versus information-sharing apps. Information-seeking apps include categories as maps, education, news, shopping, traffic, travel and games. While informationsharing apps include categories such as social networking.

Generally, m-apps provide customers with convenience in searching for, browsing and comparing various offers, posting and sharing their reviews and recommendations about products, buying and choosing among different payment options (Kapoor and Vij, 2018; Thamaraiselvan et al., 2019). Thus, they are perceived as more attractive, convenient and efficient than shopping from bricks and motor stores (Nair and Bhattacharyya, 2019). While, for companies, m-apps provide a competitive edge, increase brand awareness, enhance brand experience, improve engagement and consequently increase sales (Kapoor and Vij, 2018; Alalwan, 2020). Hence, they are considered as an attractive 
Measuring Consumers' Intention to Use Aggregator Food Ordering ...

Dr/ Sally Raouf Ragheb Garas

marketing communications tool for both large and small business companies.

Indeed, small and medium sized enterprises (SMEs) collaborate with other external parties to include m-apps to their marketing communications tools (Persaud and Azhar, 2012, Eze et al., 2018). Therefore, one of the business models used by many companies, large and small, is the aggregator business model which enables the consumer to choose from a wide variety of product/service providers registered on the app portal. These providers are then charged with a fixed profit margin of the orders in return for delivering the item(s) to the consumer or for reserving the service (Thamaraiselvan et al., 2019).

Having a closer view of various food-delivery m-apps, it can be observed that aggregator m-apps are in fact used by both small and large food providers and are offered, in many cases, in conjunction with a business branded m-app, which imply a response from the business side to the changes in consumers' shopping behavior. Clearly, until recently, food ordering was done in a traditional way. More specifically, consumers used to order food by calling a restaurant, ordering food from its menu, then the food was delivered to them by the restaurant. However, developments in m-apps and COVID19 consequences and precautions that entail social distancing and avoid waiting in closed places encouraged many consumers to use m-apps rather than follow the traditional way, especially that m-apps provide 
Measuring Consumers' Intention to Use Aggregator Food Ordering ...

Dr/ Sally Raouf Ragheb Garas

around the clock access, reviews and recommendations (Kapoor and Vij, 2018; Alalwan, 2020).

Egypt is considered one of the leading markets in the Middle East and North Africa (MENA) region in developing and using food ordering and delivery m-apps. Indeed, it has witnessed the first aggregator food ordering platform in the region (Otlob). Otlob food delivery was founded in 1999 and has undergone several acquisitions across twenty years as well as many developments, including its user-friendly and attractive m-app and its partnering with a large number of global and local restaurants and food chains. In 2020, it was acquired by an UAE company, and its brand name changed from Otlob to Talabat. The company expanded its business portfolio and started offering its services for ordering and delivering grocery and pharmaceutical items, in addition to its restaurant food ordering and delivery (Talabat.com). Recently, other food-ordering aggregator m-apps have been introduced to the Egyptian market, such as Elmenus, Akelni, Ubereat (Similarweb.com). These aggregator m-apps enable the user to search, compare, select and order from a variety of food service providers

\subsection{Technology Acceptance Model (TAM) and Hypotheses Development}

Researchers have studied consumers' mobile marketing adoption by utilizing the Technology Acceptance Model (TAM) (Davis, 1989) which is the theoretical basis of the current study. TAM 
Measuring Consumers' Intention to Use Aggregator Food Ordering ...

Dr/ Sally Raouf Ragheb Garas

has proven to have high explanatory power in identifying users' acceptance and adoption of new technology across countries and various study contexts (Gao and Bai, 2014; Marangunic and Granic, 2015). TAM is adapted from the theory of reasoned action (TRA) and the theory of planned behavior (TPB). It holds that perceived usefulness and perceived ease of use predict intention to use a new technology which in turn predicts actual usage (Gao and Bai, 2014). The main theory has undergone a number of modifications to increase its predictive validity. These modifications are classified by Marangunic and Granic (2015) into four categories. firstly, examining predictors of perceived usefulness and perceived ease of use. Secondly, studying factors from other technology acceptance theories such as subjective norms, risk and trust. Thirdly, including moderating variables as age and gender and finally includes measures as attitudes towards technology.

As mentioned earlier, m-apps are alternative technological solutions to the traditional food ordering methods, thus, the role of consumer technology involvement on intention to use the mapp needs to be examined. Consequently, the current research will expand TAM to include technology involvement as a predictor to intention to use m-apps, in addition to perceived ease of use and perceived usefulness. 
Measuring Consumers' Intention to Use Aggregator Food Ordering ...

Dr/ Sally Raouf Ragheb Garas

2.2.1 Perceived Ease of Use

Perceived ease of use is the extent a person believes that using the new technology will be free of effort (Marangunic and Granic, 2015). Previous findings show that perceived ease of use significantly impacts intention to adopt a given technology (e.g., Davis, 1989; Gao and Bai, 2014; Bakhsh, Mahmood and Sangi, 2017; Ozturk et al., 2016, Chakraborty, 2020). Therefore, $\mathbf{H 2}$ is proposed as:

H1: Perceived ease of use has a positive impact on intention to use aggregator food delivery $\mathrm{m}$-apps

\subsubsection{Perceived Usefulness}

Perceived usefulness is the degree a person believes that the new technology will make his/her daily life easier (Marangunic and Granic, 2015). Perceived usefulness is a direct outcome of perceived ease of use (Davis, 1989; Marangunic and Granic, 2015). The more the potential users understand the benefits of the new technology communicated to them, the more they will perceive its usefulness in facilitating their daily lives (Gao and Bai, 2014). Previous studies assert that perceived usefulness significantly influences the intention of users to adopt/accept the new technology or their intention to use m-apps in various contexts. Such as, dietary and fitness apps in Tiwan (Chen and Lin, 2018), electronic toll collection app in China (Gao and Bai, 2014), mobile learning apps in Pakistan (Bakhsh, Mahmood and Sangi, 2017), hotel apps in the USA (Kim, 2016) and healthcare 
Measuring Consumers' Intention to Use Aggregator Food Ordering ...

Dr/ Sally Raouf Ragheb Garas

m-app in India (Chakraborty, 2020). Moreover, from a B2B perspective, Brandon-Jones and Kauppi (2018) indicate that perceived usefulness of e-procurement systems in the Netherlands has a significant impact on users' intention to use it.

\section{Hence, $\mathrm{H2}$, and $\mathrm{H3}$ is stated as follows:}

H2: Perceived ease of use has a positive impact on perceived usefulness of aggregator food delivery m-apps

H3: Perceived usefulness has positive impact on intention to use aggregator food delivery m-Apps

\subsubsection{Technology involvement}

Generally, consumer involvement is the level of interest in or attention directed towards a focal object by a consumer (CalvoPorral and Nieto-Mengotti, 2019). Simply put, it is the perceived personal relevance of an object, to a consumer, resulting in an interest in that object (Mittal and Lee, 1989; O'Cass, 1989; Stewart et al., 2019). Involvemenet has been studied in marketing since the 1960s and has received much interest since then. In fact, scholars have worked on several conceptualizations and operationalization of the concept (Stewart et al., 2019). According to Mittal (1989) there are different types of involvement, referring to different focal objects. That is to say, a consumer can be involved with a product, with a purchase decision (or the buying process) and with a product's marketing communications or advertisements (O'Class, 2000). Moreover, involvement can be enduring or situational. The former is 
Measuring Consumers' Intention to Use Aggregator Food Ordering ...

Dr/ Sally Raouf Ragheb Garas

constant across consumption situations while the latter varies across situations for an individual (Calvo-Porral and NietoMengotti, 2019; Sarker and Sarkar, 2019). Furthermore, researchers indicate that involvement consists of both affective and cognitive components which may drive consumers behavioral responses, such as attention, processing, search and adoption (Morosan and DeFranco, 2016; Sarker and Sarkar, 2019).

Clearly, the level of a consumers' involvement depends on the person's needs, values and interests. In other words, a consumer who is highly involved with a focal object, believes and perceives that it is important to meet certain consumption values and needs on his/her side (Sarker and Sarkar, 2019). The relevant focal object can be a product class (category), a brand, a purchase decision, an advertising (Zaichkowsky, 1985; Mittal, 1989; Zaichkowsky, 1994; O’Class, 2000) or any other focal object. Since aggregator $\mathrm{m}$-apps are considered digital platforms for displaying different brands of a given product category on portable devices. It is argued that consumers adopting m-apps are likely to be involved with technology. That is, they perceive its relevance in meeting their needs and find it interesting to learn more about it. Hence, technology involvement can be defined as the extent to which a consumer perceives technology as relevant in meeting his/her needs (Calvo-Porral and NietoMengotti, 2019). 
Measuring Consumers' Intention to Use Aggregator Food Ordering ...

Dr/ Sally Raouf Ragheb Garas

Although not previously studied in the context of m-apps and TAM testing. However, previous research indicates that highly technology involved consumers experience greater impact of the mobile service quality on their loyalty to the service provider (Calvo-Porral and Nieto-Mengotti, 2019). Moreover, app involvement has significant impacts on intention to use hotel mapps (Morosan and DeFranco, 2016), and Location Based Service retail m-apps (Kang et al., 2015) and on brand loyalty of service m-apps (Sarker and Sarkar, 2019). Accordingly, it is expected that consumers using aggregator food ordering and delivery m-apps are involved in technology which makes them shift their buying from calling a restaurant to order food to ordering food using the m-apps (Stewart et al., 2019; Mou et al., 2020). Therefore, the following is proposed:

H4: Technology involvement has positive impact on intention to use aggregator food delivery m-Apps

\section{The Research Model}

Based on the mentioned hypotheses, the proposed research model is shown in Figure (1). 
Measuring Consumers' Intention to Use Aggregator Food Ordering ...

Dr/ Sally Raouf Ragheb Garas

Figure (1)

Proposed Research Model

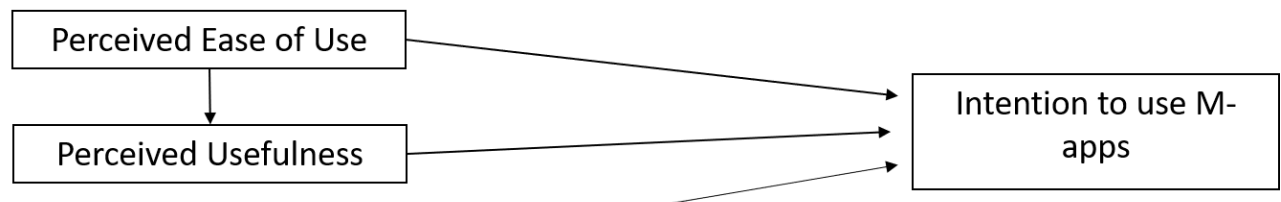

Technology Involvement

\section{3- Research Methodology}

3.1. Population of the study and the target sample

The population of the study include all users of aggregator food ordering and delivery m-apps. According to Datareportal.com, the number of mobile subscribers in Egypt in January 2020 were 92.71 million, which is equivalent to $91 \%$ of the total population. Indeed, many mobile subscribers have more than one subscription and not all mobile owners use mobile apps. Consequently, it was difficult to obtain a sampling frame for the population of the study and hence, it was not possible to use a probability sampling technique.

Since a sample size of 400 is considered adequate for populations greater than 5000 (Lunenburg and Irby, 2008). Therefore, the target sample size for the current research was 400 .

\subsection{Data Collection}

Data was gathered from a convenience sample. Out of the 400 targeted, 306 responded, from whom 257 used at least one of the 
Measuring Consumers' Intention to Use Aggregator Food Ordering ...

Dr/ Sally Raouf Ragheb Garas

aggregator food ordering m-apps and thus their responses were analyzed. The rest reported that they do not use any aggregator food delivery m-apps (the profile of aggregator food ordering and delivery m-app users is shown in table (1)).

A questionnaire was used to gather data from respondents. The questionnaire started by introducing respondents to the purpose of the study, and defining the meaning of aggregator food delivery m-apps. This introduction was followed by a screening question, asking respondents to indicate whether they use any of the aggregator food ordering and delivery m-apps and examples of such apps were listed (e.g. Talabat and Elmanus). Respondents who answered yes were included in the analysis.

Questionnaire items were developed based on validated scales, the questionnaire was developed in English, translated to Arabic and then translated back to English. Items were reviewed by one assistant professor of marketing and one management lecturer in order to assess the face validity of the variables. Then it was pilot-tested for clarity and comprehension among 30 respondents.

\subsection{Measures}

Research variables were measured using a five-point Likert Scale. Perceived ease of use and perceived usefulness were adopted from Davis (1989), purchase intention was adapted from Kalinic et al. (2020). Technology involvement items were adapted from Mittel (1995) consumer involvement profile. Questionnaire items are shown in table (3). 
Measuring Consumers' Intention to Use Aggregator Food Ordering ...

Dr/ Sally Raouf Ragheb Garas

\section{4- Data Analysis and Findings}

\subsection{The descriptive analysis of the respondents'} characteristics

Table (1) shows the profile of respondents. Where, $55.1 \%$ of aggregator food ordering and delivery $\mathrm{m}$-apps are males, the rest are females. $31.4 \%$ of the sample belongs to the age group 20 to less than $30,22.8 \%$ are 30 years old and less than 40 and $16.6 \%$ are 40 but less than 50 years old. These results indicate that users of this kind of m-apps belong to the youth and middle-aged segments. Additionally, more than half of the sample are married (53.9\%) and $43.2 \%$ of them hold a university degree. The majority of them are employed (59.8\% ) or students $(31.7 \%)$.

\section{Table (1)}

\section{Characteristics of Aggregator Food Ordering and Delivery M-apps}

\begin{tabular}{|l|l|c|c|}
\hline \multicolumn{1}{|c|}{ Demographic Variables } & \multicolumn{1}{|c|}{ Variable } & Frequency & Percent \\
\hline Gender & Male & 144 & 55.1 \\
& Female & 113 & 43.9 \\
\hline Age & less than 20 & 38 & 14.8 \\
& from 20-less than & & 31.4 \\
& 30 & 81 & 22.8 \\
& 30-less than 40 & 59 & 16.6 \\
& 40 less than 50 & 42 & 11.5 \\
& 50- less than 60 & 30 & 2.9 \\
\hline \multirow{2}{*}{ Marital status } & 60 and more & 7 & 46.1 \\
& not married & 118 & 53.9 \\
\hline Last educational degree & married & 139 & 25.7 \\
\cline { 2 - 5 } & High school & 66 & \\
\cline { 2 - 5 } & & & \\
& & & \\
& & &
\end{tabular}


Measuring Consumers' Intention to Use Aggregator Food Ordering ...

Dr/ Sally Raouf Ragheb Garas

\begin{tabular}{|l|l|c|c|}
\hline obtained & $\begin{array}{l}\text { University degree } \\
\text { Post graduate } \\
\text { degree }\end{array}$ & $\begin{array}{c}111 \\
80\end{array}$ & $\begin{array}{c}43.2 \\
31.1\end{array}$ \\
\hline \multirow{3}{*}{ Employment status } & Employed & 154 & 59.8 \\
\cline { 2 - 4 } & Do not work & 22 & 8.5 \\
\cline { 2 - 4 } & Student & 81 & 31.7 \\
\hline
\end{tabular}

\subsection{Preliminary analysis}

Before testing the research hypotheses, reliability and validity of variables were tested.

4.2. 1. Reliability of the research variables

In order to assess the consistency and stability of measures, composite reliability $(\mathrm{CR})$ of all research constructs should meet the recommended cutoff point for establishing CR which is 0.70 (Malhotra, 2010). As shown in Table 2, CR varied was between 0.878 (perceived usefulness) to 0.942 (technology involvement). Moreover, Cronbach's alpha ranged from 0.812 (perceived usefulness) to 0.917 (technology involvement).

Table (2) Reliability Measures

\begin{tabular}{|l|c||c|}
\hline \multicolumn{1}{|c|}{ Measures } & $\begin{array}{c}\text { Composite } \\
\text { reliability }\end{array}$ & $\begin{array}{c}\text { Cronbach's } \\
\text { Alpha }\end{array}$ \\
\hline Perceived ease of use & 0.902 & 0.836 \\
\hline Perceived usefulness & 0.878 & 0.812 \\
\hline Tech involvement & 0.942 & 0.917 \\
\hline Intention to use food delivery m-apps & 0.913 & 0.855 \\
\hline
\end{tabular}


Measuring Consumers' Intention to Use Aggregator Food Ordering ...

Dr/ Sally Raouf Ragheb Garas

4.2.2 Validity of the research variables

Convergent validity was assessed by examining the minimum requirements for factor loadings and the Average Variance Extracted (AVE) of the variables. All factor loadings met the cutoff point of 0.40 as shown in Table 3. Furthermore, the AVE of all items by their respective constructs were greater than the variance unexplained (that is AVE> 0.50) (Fornell and Larcker, 1981), as shown in Table 4 . Hence convergent validity was established.

Table (3) Loadings of items

\begin{tabular}{|c|l|c|}
\hline Variable & \multicolumn{1}{|c|}{ Item } & Loading \\
\hline Ease of Use & $\begin{array}{l}\text { Learning to use aggregate } \\
\text { food ordering and delivery m- } \\
\text { apps would be easy for me }\end{array}$ & \\
\cline { 2 - 4 } & $\begin{array}{l}\text { it is easy to find what I need } \\
\text { when I use aggregate food } \\
\text { ordering and delivery m-apps }\end{array}$ & \\
\cline { 2 - 4 } & $\begin{array}{l}\text { I find aggregate food ordering } \\
\text { and delivery m-apps easy to use }\end{array}$ & .890 \\
\hline Perceive Usefulness & $\begin{array}{l}\text { Using aggregator food } \\
\text { ordering and delivery m-apps } \\
\text { would enable me to order } \\
\text { food more quickly. }\end{array}$ & \\
\cline { 2 - 4 } & $\begin{array}{l}\text { Using aggregator food } \\
\text { ordering and delivery m-apps } \\
\text { helps me order food with less } \\
\text { effort }\end{array}$ & \\
\hline & $\begin{array}{l}\text { aggregator food ordering and } \\
\text { delivery m-apps helps me } \\
\text { compare prices of restaurants* }\end{array}$ & \\
\hline
\end{tabular}


Measuring Consumers' Intention to Use Aggregator Food Ordering ...

Dr/ Sally Raouf Ragheb Garas

\begin{tabular}{|c|c|c|}
\hline Variable & Item & Loading \\
\hline & $\begin{array}{l}\text { I can have new discounts } \\
\text { when using aggregator food } \\
\text { ordering and delivery mobile } \\
\text { apps* }\end{array}$ & .685 \\
\hline & $\begin{array}{l}\text { I find aggregator food } \\
\text { ordering and delivery m-apps } \\
\text { useful when I need to order } \\
\text { food }\end{array}$ & .772 \\
\hline & $\begin{array}{l}\text { Aggregator food ordering and } \\
\text { delivery m-apps makes } \\
\text { ordering food easier }\end{array}$ & .774 \\
\hline \multirow[t]{4}{*}{$\begin{array}{l}\text { Technology } \\
\text { Involvement }\end{array}$} & $\begin{array}{lcc}\text { I } & \text { consider } & \text { technology } \\
\text { important to me } & \end{array}$ & .843 \\
\hline & Technology means a lot to me & .924 \\
\hline & $\begin{array}{l}\text { I consider technology an } \\
\text { important part of my life }\end{array}$ & .924 \\
\hline & $\begin{array}{l}\text { I am very concerned with } \\
\text { technology }\end{array}$ & .892 \\
\hline \multirow[t]{3}{*}{$\begin{array}{l}\text { Intention to use the } \\
\text { m-app }\end{array}$} & $\begin{array}{l}\text { I am likely to use aggregator } \\
\text { food ordering and delivery m- } \\
\text { apps in the future }\end{array}$ & .898 \\
\hline & $\begin{array}{l}\text { Given the opportunity, I will } \\
\text { use aggregator food ordering } \\
\text { and delivery m-apps for } \\
\text { ordering food }\end{array}$ & .875 \\
\hline & $\begin{array}{l}\text { Most probably, I will use } \\
\text { aggregator food ordering and } \\
\text { delivery } \mathrm{m} \text {-apps in the future }\end{array}$ & .873 \\
\hline
\end{tabular}

* Developed by the researcher

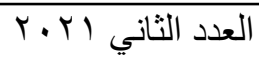


Measuring Consumers' Intention to Use Aggregator Food Ordering ...

Dr/ Sally Raouf Ragheb Garas

Table (4 ) Average Variance Extracted (AVE)

\begin{tabular}{|l|c|}
\hline \multicolumn{1}{|c|}{ Measures } & $\begin{array}{c}\text { Average Variance Extracted } \\
\text { (AVE) }\end{array}$ \\
\hline Perceived ease of use & 0.755 \\
\hline Perceived usefulness & 0.548 \\
\hline Tech involvement & 0.803 \\
\hline Intention to use food delivery m-apps & 0.779 \\
\hline
\end{tabular}

4.2.3. Confirmatory Factor Analysis

Additionally, Confirmatory Factor Analysis (CFA) was run to test the measurement model. As shown in Table 5, considering the goodness of fit indexes values, results show an adequate fit. More specifically, GFI, NFI and CFI values range between 0.893 and 0.988 which is between the adequate range (0 and 1). Moreover, the value of DMIM/DF is between 1.836 and 2.169 which is less than the cutoff point of 3 . Furthermore, the value of RMSEA is between 0.05 and 0.07 also less than 0.08 (Browne and Cudeck, 1992; cited in Morosan and DeFranco, 2016).

Table (5) Confirmatory Factor Analysis (CFA)

\begin{tabular}{|l|c|c|c|c|c|}
\hline \multirow{2}{*}{ Measures } & \multicolumn{5}{|c|}{ Indicators } \\
\cline { 2 - 6 } & GFI & NFI & CFI & $\begin{array}{c}\text { CMIN } \\
\text { /DF }\end{array}$ & RMSEA \\
\hline Perceived ease of use & 0.946 & 0.913 & 0.923 & 2.169 & 0.07 \\
\hline Perceived usefulness & 0.933 & 0.915 & 0.893 & 1.981 & 0.06 \\
\hline Tech involvement & 0.988 & 0.984 & 0.986 & 1.953 & 0.05 \\
\hline $\begin{array}{l}\text { Intention to use food } \\
\text { delivery m-apps }\end{array}$ & 0.966 & 0.934 & 0.925 & 1.836 & 0.05 \\
\hline
\end{tabular}


Measuring Consumers' Intention to Use Aggregator Food Ordering ...

Dr/ Sally Raouf Ragheb Garas

\subsection{Hypotheses Testing}

To measure the relationships between perceived ease of use, perceived usefulness and technology involvement and intention to use the m-app, both simple and multiple regression were conducted.

\subsubsection{Testing the impact of perceived ease of use on intention to use aggregator food ordering and delivery m-apps}

As shown in table 6, perceived ease of use significantly impacts intention to use aggregator m-apps $(\beta=0.391, \mathrm{p}<0.05)$. Thus, H1 is supported. Moreover, $\mathrm{R}^{2}$ value of perceived ease of use is 0.153 which points out that it explains $15.3 \%$ of intention to use food delivery m-apps.

Table (6): Simple regression analysis for perceived ease of use on intention to use food delivery m-apps

\begin{tabular}{|c|c|c|c|c|c|}
\hline $\begin{array}{c}\text { Dependent } \\
\text { Variable }\end{array}$ & $\begin{array}{c}\text { Independent } \\
\text { Variable }\end{array}$ & B & T-Value & Sig. & Decision \\
\hline $\begin{array}{c}\text { Intention to use } \\
\text { food delivery } \\
\text { m-apps }\end{array}$ & $\begin{array}{c}\text { Perceived ease } \\
\text { of use }\end{array}$ & 0.391 & 6.631 & 0.000 & Supported \\
\hline $\mathbf{R}^{2}=\mathbf{0 . 1 5 3}$ & $\begin{array}{l}\text { F- Value }=\mathbf{4 3 . 9 6 5} \\
\text { Sig } \mathbf{0 . 0 0 0}\end{array}$ \\
\hline
\end{tabular}

4.3.2. Testing the impact of perceived usefulness on intention to use aggregator food ordering and delivery m-apps

As shown in table 7, perceived usefulness significantly impacts intention to use aggregator m-apps at $\beta=0.602, \quad \mathrm{p}<0.05$. Therefore, $\mathrm{H} 3$ is supported. $\mathrm{R}^{2}$ of perceived usefulness is 0.362 
Measuring Consumers' Intention to Use Aggregator Food Ordering ...

Dr/ Sally Raouf Ragheb Garas

indicating that perceived usefulness explains $36.2 \%$ of intention to use food delivery m-apps.

Table (7): Simple regression analysis for perceived usefulness on intention to use food delivery m-apps

\begin{tabular}{|c|c|c|c|c|c|}
\hline $\begin{array}{c}\text { Dependent } \\
\text { Variable }\end{array}$ & $\begin{array}{c}\text { Independent } \\
\text { Variable }\end{array}$ & $\mathbf{B}$ & T-Value & Sig. & Decision \\
\hline $\begin{array}{c}\text { Intention to use } \\
\text { food delivery } \\
\text { m-apps }\end{array}$ & $\begin{array}{c}\text { Perceived } \\
\text { usefulness }\end{array}$ & 0.602 & 11.742 & 0.000 & Supported \\
\hline $\mathbf{R}^{2}=\mathbf{0 . 3 6 2}$ & & $\begin{array}{c}\text { F- Value }=\mathbf{1 3 7 . 8 8 0} \\
\text { Sig }=\mathbf{0 . 0 0 0}\end{array}$ \\
\hline
\end{tabular}

4.3.3. Testing the impact of technology involvement on intention to use aggregator food ordering and delivery $\mathrm{m}$ apps

According to table 8, technology involvement significantly impacts intention to use aggregator m-apps at $\beta=0.213, p<0.05$. Consequently, $\mathrm{H} 4$ is supported. $\mathrm{R}^{2}$ of technology involvement is 0.123 indicating that perceived usefulness explains $12.3 \%$ of intention to use food delivery m-apps.

Table (8): Simple regression analysis for technology involvement on

Intention to use food delivery m-apps

\begin{tabular}{|c|c|c|c|c|c|}
\hline $\begin{array}{c}\text { Dependent } \\
\text { Variable }\end{array}$ & $\begin{array}{c}\text { Independent } \\
\text { Variable }\end{array}$ & $\mathbf{B}$ & T-Value & Sig. & Decision \\
\hline $\begin{array}{c}\text { Intention to use } \\
\text { food delivery } \\
\text { m-apps }\end{array}$ & $\begin{array}{c}\text { Tech } \\
\text { involvement }\end{array}$ & 0.213 & 5.832 & 0.000 & Supported \\
\hline $\mathbf{R}^{2}=\mathbf{0 . 1 2 3}$ & $\begin{array}{c}\text { F- Value }=\mathbf{3 4 . 0 0 6} \\
\text { Sig }=\mathbf{0 . 0 0 0}\end{array}$ \\
\hline
\end{tabular}


Measuring Consumers' Intention to Use Aggregator Food Ordering ...

Dr/ Sally Raouf Ragheb Garas

4.3.4. Testing the impact of perceived ease of use, perceived usefulness and technology involvement on intention to use the m-apps

Table 9 shows that the three independent variables have a significant positive impact on intention to use aggregator food delivery m-apps. Where perceived usefulness has the greatest impact $(\beta=0.503, p<0.05)$, followed by technology involvement $(\beta=0.206, p<0.05)$ then perceived ease of use $(\beta=0.116, p<0.05)$. Moreover, Table 9 indicates that the $\mathrm{R}^{2}$ of the whole model is 0.402 which meets the recommended level of $R^{2}$ which is 0.10 (Falk and Miller, 1992).

Table (9): Multiple-regression analysis for factors impacting intention to use food delivery m-apps

\begin{tabular}{|c|c|c|c|c|c|c|}
\hline $\begin{array}{c}\text { Dependent } \\
\text { Variable }\end{array}$ & $\begin{array}{c}\text { Independent } \\
\text { Variables }\end{array}$ & B & $\begin{array}{c}\text { T- } \\
\text { Value }\end{array}$ & Sig. & Decision & $\begin{array}{c}\text { Rating } \\
\text { List }\end{array}$ \\
\hline \multirow{3}{*}{$\begin{array}{c}\text { Intention to } \\
\text { use food } \\
\text { delivery m- } \\
\text { apps }\end{array}$} & $\begin{array}{l}\text { Perceived ease } \\
\text { of use }\end{array}$ & 0.116 & 2.244 & 0.037 & Supported & 3 \\
\hline & $\begin{array}{l}\text { Perceived } \\
\text { usefulness }\end{array}$ & 0.503 & 8.703 & 0.000 & Supported & 1 \\
\hline & $\begin{array}{l}\text { Tech } \\
\text { involvement }\end{array}$ & 0.206 & 3.920 & 0.000 & Supported & 2 \\
\hline \multicolumn{2}{|l|}{$R^{2}=0.402$} & \multicolumn{5}{|c|}{$\begin{array}{l}\text { F- Value }=53.889 \\
\text { Sig }=0.000\end{array}$} \\
\hline
\end{tabular}

In order to test the potential mediating impact of perceived usefulness, mediation test was conducted, results shown in table 10 
Measuring Consumers' Intention to Use Aggregator Food Ordering ...

Dr/ Sally Raouf Ragheb Garas

indicate that perceived usefulness mediates the relationship between perceived ease of use and intention to use aggregator food delivery m-apps $(\beta=0.193, p<0.05)$. Hence, $\mathrm{H} 2$ is supported.

Table 10 Indirect Effects Analysis

\begin{tabular}{|c|c|c|c|c|c|c|c|}
\hline \multicolumn{3}{|c|}{ Indirect Path } & $\boldsymbol{\beta}$ & $\begin{array}{c}\text { Std. } \\
\text { E }\end{array}$ & $\begin{array}{c}\text { t- } \\
\text { Value }\end{array}$ & Sig. & Decision \\
\hline Dep & Med & Indep & Indirect & Perced \\
ease of use & $\begin{array}{c}\text { Perceived } \\
\text { usefulness }\end{array}$ & $\begin{array}{c}\text { Intention to } \\
\text { use food } \\
\text { delivery m- } \\
\text { apps }\end{array}$ & 0.193 & 0.048 & 3.178 & 0.000 & Supported \\
\hline
\end{tabular}

\section{Discussion and Implications}

The study uses the TAM as a theoretical basis for hypotheses development and extends it by examining the impact technology involvement of m-app users on their intention to use aggregator food ordering and delivery $\mathrm{m}$-apps. Results regarding the impacts of perceived ease of use and perceived usefulness on intention to use aggregator food ordering $\mathrm{m}$-apps are consistent with previous research findings (Davis, 1989; Bakhsh, Mahmood and Sangi, 2017; Ozturk, 2016; Chakraborty, 2020; Chen and Lin, 2018). In fact, findings of the current research indicate that perceived usefulness has the greatest impact on intention to use the m-apps and that it mediates the relationship between perceived ease of use and intention to use the m-app, a result which is also consistent with previous studies (Davis, 1989; Marangunic and Granic, 2015). Finally, the current study indicates that users' 
Measuring Consumers' Intention to Use Aggregator Food Ordering ...

Dr/ Sally Raouf Ragheb Garas

technology involvement significantly impacts intention to use aggregator mobile app. A result which implies that technologyoriented consumers are more likely to use m-apps, which is the main contribution of this research.

Based on the research findings, a number of implications are proposed for aggregator food ordering and delivery m-app providers. First, aggregator m-app providers can use the technology involvement level of app users as one of the bases of segmenting their markets. Second, they can provide engaging technology-oriented marketing communications to their users, tailoring these communications based on the level of technology involvement of their audience. Third, providers can work with app developers to offer more useful technology-oriented services on their apps, such as customized applications, voice search and feedback, 3D product presentations and secure and easy payment options, such features need to be displayed in a user-friendly mode to enhance perceived ease of use. Fourthly, the downloading, opening, browsing app speed is essential to enhance perceived ease of use. Finally, small and medium sized food providers, having no branded m-apps, need to select carefully the aggregator food ordering and delivery platform they will employ for their marketing and delivery services. They should give a priority to features that support perceived usefulness. 
Measuring Consumers' Intention to Use Aggregator Food Ordering ...

Dr/ Sally Raouf Ragheb Garas

\section{6- Limitations and Suggested Future Research}

First, the current study examines aggregator food ordering mapps, future studies can examine other contexts and m-app types. Second, the research examines the basic TAM model predictors and extends it by studying the impact of the technology involvement on users' intention to use the app. Future research can include other predictors and moderators to the extendable TAM model such as perceived risk and users' demographics. Third, a mixed research design can be used to validate the survey findings. Fourth, a quota sample can be used to better represent the population. Finally, the current study examines intention to use aggregator food ordering and delivery m-apps in general. Future studies can be applied on one specific aggregator food ordering m-apps to gain deeper insights regarding customers' perceptions. 
Measuring Consumers' Intention to Use Aggregator Food Ordering ...

Dr/ Sally Raouf Ragheb Garas

\section{References}

Alalwan, A. A. (2020). Mobile food ordering apps: An empirical study of the factors affecting customer e-satisfaction and continued intention to reuse. International Journal of Information Management, 50(February 2019), 28-44.

Bakhsh, M., Mahmood, A., \& Sangi, N. A. (2017). Examination of factors influencing students and faculty behavior towards m-learning acceptance. The International Journal of Information and Learning Technology.

Brandon-Jones, A., \& Kauppi, K. (2018). Examining the antecedents of the technology acceptance model within e-procurement. International Journal of Operations \& Production Management.

Browne, M. W., \& Cudeck, R. (1992). Alternative ways of assessing model fit. Sociological methods \& research, 21(2), 230-258. In : Morosan, C., \& DeFranco, A. (2016). Modeling guests' intentions to use mobile apps in hotels: The roles of personalization, privacy, and involvement. International Journal of Contemporary Hospitality Management, 28(9), 1968-1991.

Calvo-Porral, C., \& Nieto-Mengotti, M. (2019). The moderating influence of involvement with ICTs in mobile services. Spanish Journal of Marketing - ESIC, 23(1), 25-43. https://doi.org/10.1108/SJME-082018-0036

Chakraborty, D. (2020) Elements impacting the utilization expectation of various health care apps in India: a study conducted on smartphone users. Foresight, 22(3), 385-400.

Chen, M. F., \& Lin, N. P. (2018). Incorporation of health consciousness into the technology readiness and acceptance model to predict app download and usage intentions. Internet Research. 
Measuring Consumers' Intention to Use Aggregator Food Ordering ...

Dr/ Sally Raouf Ragheb Garas

Code 95 Egypt Web Technologies. https://code95.com/blog/most-popularapps-in-egypt/ (Accessed 27/11/2020).

Davis, F. (1989). Perceived usefulness, perceived ease of use and user acceptance of information technology. MIS Quarterly, 13, 319-340.

Datareportal https://datareportal.com/reports/digital-2020-egypt (Accessed 27/11/2020).

Fornell, C., and Larcker, D. F. (1981). Evaluating structural equation models with unobservable variables and measurement error. Journal of Marketing Research, 18 (1), 39-50

Falk, R. F., \& Miller, N. B. (1992). A primer for soft modeling. University of Akron Press.

Kalinic, Z., Liebana-Cabanillas, F., Munoz-Leiva, F. and Marinkovic, V. (2020). The moderating impact of gender on acceptance of peer-topeer mobile payment systems. International Journal of Bank Marketing, 38(1), 138-158.

Kang, J. Y. M., Mun, J. M., \& Johnson, K. K. P. (2015). In-store mobile usage: Downloading and usage intention toward mobile locationbased retail apps. Computers in Human Behavior, 46, 210-217. https://doi.org/10.1016/j.chb.2015.01.012

Kapoor, A. P., \& Vij, M. (2018). Technology at the dinner table: Ordering food online through mobile apps. Journal of Retailing and Consumer Services, 43, 342-351.

Kushwaha, G. S., \& Agrawal, S. R. (2016). The impact of mobile marketing initiatives on customers' attitudes and behavioural outcomes. Journal of Research in Interactive Marketing.

Kim, J. (2016). An extended technology acceptance model in behavioral intention toward hotel tablet apps with moderating effects of gender and age. International Journal of Contemporary Hospitality Management, 28(8), 1535-1553. 
Measuring Consumers' Intention to Use Aggregator Food Ordering ...

Dr/ Sally Raouf Ragheb Garas

Hew, J., Lee, V., Ooi, J., Wei,J. (2015).What catalyses mobile apps usage intention: an empirical analysis. Industrial Management \& Data Systems. 115 (7), 1269-1291.

Leppaniemi, M. and Karjaluoto, H. (2008). Mobile marketing: from marketing strategy to mobile marketing campaign implementation. International Journal of Mobile Marketing, 3(1), 50-61.

Lunenburg, F., and Irby, B. (2008). Writing a successful thesis or dissertation: tips and strategies for students in the social and behavioral sciences. Corwin Press

Leon, S. (2018). Service mobile apps: a millennial generation perspective. Industrial Management \& Data Systems. 118 (9), 1837-1860.

Malhotra, N. (2010), Marketing research: an applied orientation, (6th ed.). Global Edition, Prentice Hall, N.J.

Marangunic, N. and Granic, A. (2015). Technology acceptance model: a literature review from 1986 to 2013. Univ Access Inf Soc, 14, 81-95.

Mittal, B., \& Lee, M. S. (1989). A causal model of consumer involvement. Journal of Economic Psychology, 10(3), 363-389. https://doi.org/10.1016/0167-4870(89)90030-5

Mittal, B. (1989). Measuring purchase- decision involvement. Psychology \& Marketing, 6(2), 147-162.

Mittal, B. (1995). A comparative analysis of four scales of consumer involvement. Psychology \& marketing, 12(7), 663-682.

Mou, J., Zhu, W., \& Benyoucef, M. (2020). Impact of product description and involvement on purchase intention in cross-border e-commerce. Industrial Management and Data Systems, 120(3), 567-586. https://doi.org/10.1108/IMDS-05-2019-0280

Mobile Marketing Association (2009) http://www.mmaglobal.com/news/mma-updates-definition-mobilemarketing. (Accessed 27/11/2020). 
Measuring Consumers' Intention to Use Aggregator Food Ordering ...

Dr/ Sally Raouf Ragheb Garas

Morosan, C., \& DeFranco, A. (2016). Modeling guests' intentions to use mobile apps in hotels: The roles of personalization, privacy, and involvement. International Journal of Contemporary Hospitality Management, 28(9), 1968-1991.

Nair, A. and Bhattacharyya, S. (2019). Is sustainability a motive to buy? An exploratory study in the context of mobile applications channel among young Indian consumers. Foresight, 12(2)177-199.

O'Cass, A. (2000). An assessment of consumers product, purchase decision, advertising and consumption involvement in fashion clothing. Journal of Economic Psychology, 21(5), 545-576.

Ozturk, A. B., Bilgihan, A., Nusair, K., \& Okumus, F. (2016). What keeps the mobile hotel booking users loyal? Investigating the roles of selfefficacy, compatibility, perceived ease of use, and perceived convenience. International Journal of Information Management, 36(6), 1350-1359.

Patsiotis, A., Atik, M and Perrea, T. (2020). The influence of m-marketing tools on consumer buying process: evidence from the dining sector. International Journal of Retail\& Distribution Management, 48(10), 1037-1056.

Persaud, A., \& Azhar, I. (2012). Innovative mobile marketing via smartphones: Are consumers ready?.Marketing Intelligence \& Planning.

Sarkar, J. G., \& Sarkar, A. (2019). Young adult consumers' involvement in branded smartphone based service apps: Investigating the roles of relevant moderators. Information Technology and People, 32(6), 1608-1632. https://doi.org/10.1108/ITP-04-2017-0128

Similarweb.com. $\quad$ https://www.similarweb.com/apps/top/apple/storerank/eg/food-and-drink/top-free/iphone/ [accessed on 20 May 2021] 
Measuring Consumers' Intention to Use Aggregator Food Ordering ...

Dr/ Sally Raouf Ragheb Garas

Stewart, K., Kammer-Kerwick, M., Auchter, A., Koh, H. E., Dunn, M. E., \& Cunningham, I. (2019). Examining digital video advertising (DVA) effectiveness: The role of product category, product involvement, and device. European Journal of Marketing, 53(11), 2451-2479.

Stocchi, L., Michaelidou, N., Micevski, M. (2019). Drivers and outcomes of branded mobile app usage intention. Journal of Product \& Brand Management 28(1), 28-49.

Soomro, B., Shah, N. and Memon, M. (2019). Investigating the intention to adopt smartphone apps among the entrepreneurs of a developing country. World Journal of entrepreneurship, Management and Sustainable Development, 15(4), 341-353.

Talabat.com. https://www.talabat.com/egypt [accessed on 4 March 2021]

Tang, A. (2019). A systematic literature review and analysis on mobile apps in m-commerce: implications for future research. Electronic Commerce Research and Applications, 37, 1-13.

Thamaraiselvan, N., Jayadevan, G. R., \& Chandrasekar, K. S. (2019). Digital food delivery apps revolutionizing food products marketing in India. International Journal of Recent Technology and Engineering, 8(2 Special Issue 6), 662-665.

Tsalgatidou, A., \& Pitoura, E. (2001). Business models and transactions in mobile electronic commerce: requirements and properties. Computer Networks, 37(2), 221-236.

Zaichkowsky, J. L. (1985). Measuring the involvement construct. Journal of consumer research, 12(3), 341-352.

Zaichkowsky, J. L. (1994). The personal involvement inventory: Reduction, revision, and application to advertising. Journal of advertising, 23(4), 59-70. 